\title{
A Review of the Relationship between Corporate Financial Performance and the Level of Related Party Transactions among Listed Companies on Tehran Stock Exchange
}

\author{
Ali Basalighe ${ }^{1} \&$ Ehsan khansalar ${ }^{2}$ \\ ${ }^{1}$ Department of Accounting, Qaenat Branch, Islamic Azad University, Qaenat, Iran \\ ${ }^{2}$ Departement of Accounting, Finance and Informatics, Kingston University, London, UK \\ Correspondence: Ali Basalighe, Department of Accounting, Qaenat Branch, Islamic Azad University, Qaenat, \\ Iran. E-mail: basaligheh.ali@gmail.com
}

Received: March 20, 2016

Accepted: May 3, 2016

Online Published: June 25, 2016

doi:10.5539/ijef.v8n7p330

URL: http://dx.doi.org/10.5539/ijef.v8n7p330

\begin{abstract}
The main objective of the investors to invest in stocks is to earn a profit and this is achieved by firm performance improvement. So the investors analyze various kinds of financial performance data for the different kinds of business models to determine whether some models perform better than others.

The present study aims to collect the evidences of the relationship between firm economic performance and the level of related party transactions on Tehran Stock Exchange. So far, empirical evidences are not provided to reveal a clear picture of the reasons behind the related party transactions in Iran. In the case of opportunistic behavior in transactions, it is expected that the level of related party transactions has a relationship with economic performance variables. The research data have been collected over 1387-1393 for companies listed on Tehran Stock Exchange and to test the hypotheses, multivariate regression analysis of panel data is used. The results indicate that at a 95\% confidence level, the economic value added (EVA), refined economic value added (Reva) and the market value added (MVA) variables have a significant relationship with the level of related party transactions.
\end{abstract}

Keywords: related party transactions, Economic Value Added (EVA), Refined Economic Value Added (REVA), Market Value Added (MVA)

\section{Introduction}

The development of rapidly growing numbers of large different companies is one of the "outstanding characteristics of our century". The joint stock companies are formed by the growth of capital markets and attracting small and large investments in economic sectors to achieve profits such as economies of scale, diversification of investments and maximizing the overall portfolio's risk-adjusted return.

The companies that in their ownership structure managers are not necessarily wealth owners. So this case raised the issues such as agency costs and the conflicts of interest between management and shareholders. However the primary objective of financial reporting is to provide useful information for decision making. In this regard, when a firm shows higher accounting quality in its financial reporting, it can take better economic decisions. In this article a general idea of the topic and the necessity of this study are introduced then an overview of the research methods and variables are presented. The main contribution of this research is to review the relationship between corporate economic performance and the level of related party transactions in companies listed in the Tehran Stock Exchange to help financial statements users to take right financial decisions.

\section{Statement of the Problem}

Controlling shareholders transfer the assets and profits out of minority shareholders through related party transactions. The so-called tunneling is used to determine the deviation of interests at the expense of minority shareholders in the company (Johnson et al., 2000). According to the Liu and Lu (2007), tunneling is the expropriation of the minority shareholders wealth by controlling shareholders. The researchers stated that tunneling conceals the company's actual performance and controlling shareholders private profits from other stockholders which is usually detrimental to minority shareholders. In practice, this definition of tunneling is true 
for a company that transfer its profits to a related or unrelated party out of the company.

According to Accounting Standard No. 12, in Iran a related party transaction is a transfer of resources, services or obligations between related parties, regardless of whether a price is charged. According to this standard a party is a related party if any of the following conditions applies:

a-Directly or indirectly through one or more intermediates

1)-Has control or joint control over the reporting entity (Including the main business units, subsidiaries and fellow subsidiaries);

2)-Has significant influence over the reporting entity; or

3)-Has a joint control on reporting entity.

4)-Is a member of the key management personnel of the reporting entity or of a parent of the reporting entity.

b-One entity is an associate of the other entity

c-One entity is a joint venture of the other entity

d-Is a member of the key management personnel of the reporting entity or of a parent of the reporting entity.

f-Is a close member of the person's family who are identified in (a) or (d).

g-The entity is controlled or jointly controlled by the persons identified in (d) or (f) Or that a significant share of the voting rights directly or indirectly are available to them, and

h-The entity is a post-employment benefit plan for the benefit of employees of either the reporting entity or an entity related to the reporting entity. If the reporting entity is itself such a plan, the sponsoring employers are also related to the reporting entity.

Related party transactions can be done in different ways, including the purchase or sale of goods, purchase or sale of non-current assets, providing or receiving services, leasing, transfer of research and development projects, patent purchase agreement, long-term and short-term financing, guarantee and collateral agreement, and debt arbitration of the entity or by the entity on behalf of another person (Iranian accounting standard No. 12).

Controlling shareholders that own X\% of the company's stock are not satisfied but they want to own in addition some other extractable private profits from the company. In contrast, minority shareholders with $y \%$ stake in the company, do not expect to achieve their exact value, but they are underachieved because of y\% minus stake in the company and also minus what the controlling shareholders may pursue as their private interests. The rate of the private interests of controlling shareholders depends on corporate governance structure.

Based on Iranian accounting standards, control means the ability to direct the financial and operational policies of a firm to achieve economic benefits from its activities. So controlling shareholders have the power to control the core of the company's decisions and policies.

Based on Regho (2007) and Jahang et al. (2007) empirical researches, a significant portion of related party transactions are based on unfair non-market prices.

A related party relationship could have an effect on the profit or loss and financial position of an entity. Related parties may enter into transactions that unrelated parties would not.

For example, an entity that routinely sells goods to its owner at cost would probably may not routinely enter into transactions to sell goods to its other customers at cost. In addition, the transactions between related parties may not be made at the same amounts as between unrelated parties (article 8 of Iranian accounting standard 12).

The profit or loss and financial position of an entity may be affected by a related party relationships even if related party transactions do not occur. The mere existence of the relationship may be sufficient to affect the transactions of the entity with other parties. For example, a subsidiary may terminate relations with a trading partner upon the acquisition by the parent of a fellow subsidiary that is engaged in the same activity as the former trading partner. Alternatively, one party may refrain from acting because of the significant influence of another-for example, a subsidiary may be instructed by its parent not to engage in research and development. There are two proposed views about the uses of related party transactions. The first view is Propping-up hypothesis which suggests that transactions with related parties are applied in companies which have poor performances (Friedman et al., 2003). Bertrand et al. (2002) and Jiang and Wang (2010) have documented when there is incentives to meet profit targets, related party sales are used to reduce negative effects of industry shocks on listed firms profits. Another hypothesis in regard to related party transactions, is internal capital market theory which is derived from Coase (1937) and Williamson (1964) transaction cost theory. This hypothesis implies that 
related party transactions are used as an alternative to foreign trading markets. Domestic capital market has costs and benefits .The benefits include how resources are allocated and is associated with economic efficiency and maximization of utility, better coordination between different sources, faster feedback and the mutual transfer of knowledge. Costs related to the domestic capital market sectors include opportunistic behavior of managers (Charfsten \& Stein, 2000) and inefficient allocation of resources (Charfsten, 1998). These costs are mainly caused by agency costs. Ownership of agency issue is a principle topic in corporate governance. For companies with extensive properties, the main concern is how the interests of managers and shareholders are aligned although the professional managers are accountable to shareholders. In contrast, in companies with concentrated ownership structure, the basic question is how conflict of interests between controlling shareholders and minority shareholders can be resolved.

Shleifer and Vishny (1997) stressed that although large shareholders can be very effective in solving the agency problem, In this case, large owners might be costly as they can redistribute wealth in both efficient and inefficient way from minority shareholders (Shleifer \& Vishny, Large shareholders and corporate control, 1986). Cost of ownership concentration means abuse of control rights by majority shareholders to increase their wealth at the expense of minorities, Ownership concentration, aligned with more power of controlling shareholders led to the expropriation of minority shareholders (La Porta et al., 1999). Since there are several important and influential shareholders, they have different preferences in related parties transactions. What is best for the biggest shareholder, may not be best for the second- and third-largest shareholders and Private benefits of control may not be divided fairly or equally between them. When one of the major shareholders receives fewer benefits from related party transactions he/she may disagree with such transactions. So the balance of control may reduce related party transactions. In other words, control dispersion is a mechanism for interest deviation reduction (Bendsen et al., 2000). Based on the Chen and Wang (2005) research on Chinese companies over 1998-2002, there have been more balance between controlling shareholders, when the number of firms shareholders increased by more than ten percent. As a result, the amount and number of transactions with related parties decreased. With regard to the above issues the research questions are as follows:

The first question: Is there any significant relationship between economic value added (EVA) and the level of related party transactions?

The second question: Is there any significant relationship between refined economic value added (REVA) and the level of related party transactions?

The third question: Is there any significant relationship between market value added (MVA) and the level of related party transactions?

\section{Research Background}

Ismail (2006) study examined the relationship between economic value added (EVA) and total stock return. He also studied stock returns and accounting earnings and found that operating profit after Tax/net profit after tax variables as control variables in the model that increases the coefficient of determination in relation to efficiency and economic value added. In addition, he found that accruals and operating cash flow have significant effects on the economic value-added information content.

Elmir and Seboui (2008) reviewed corporate governance and the linkage between economic value added (EVA) and created shareholder value. They concluded that there was a weak correlation between economic value added (EVA) and the shareholders created value. In this study, conducted over 1998-2004, the explanatory power of the shareholders created value based on economic value added was $7 \%$.

Mittal et al. (2008) reviewed the relationship between corporate performance and the economic value-added. They used social responsibility and ethical standards to measure company performance. Their finding indicated that there was not any significant relationship between economic value added and corporate social responsibility.

Song et al. (2009), studied the relationship between corporate governance mechanisms and related party transactions in companies listed on China's stock over 2002-2006. The results showed that the level of related party transactions increased in companies with higher ownership concentration, but it reduced when second and third major shareholders had strong bargaining power. Evidences also indicate that high rewards for external managers is along with increasing related party transactions, while the aim of an average increase in the three chief executive officers (CEOs) bonuses is the reduction of related party transactions, however ,if the chief executive officer (CEO), also serves as chairman of the board the level of related party transactions is increased .

Jian and Wong (2010) pointed out propping acts by controlling shareholders through related party transactions. They used data on related-party transactions of all listed Chinese firms from 2002 to 2008. They found that 
controlling shareholders prop up earnings by using abnormal related sales. Such propping acts more prevailed in state-owned companies and in areas where the economic situation is weaker.

Anil K. Sharma, Satish Kumar (2010) presented a narrative literature review of the papers published on the economic value added (EVA). They found that economic value added was a measurement tool for firm performance which created value insider CEOs and outsider CEOs.

Yin-Hua Yeh et al. (2012) In their study explored how corporate governance affects the level of related party transactions (RPTs) in Taiwan. The empirical results showed that good corporate governance was effective in constraining related-party transactions (RPTs). The findings also indicated that if the firms plan to issue seasoned equity next period to raise its earnings, there is a positive relationship between related parties transaction and profit reduction. The internal capital market hypothesis indicates that the level of related lending and guarantee (related borrowing) is negatively correlated with the condition of an increase in capital expenditure and an increase in net working capital.

Nicola Moscariello (2013) studied the motivations behind related parties transactions in Italian listed companies. His aim was to identify the reasons behind the transactions with related parties and efficiency or opportunistic features of these transactions. Given the ownership structure in Italian companies, major shareholders use related party transactions to expropriate the wealth of minority shareholders The evidences also showed an opportunistic behavior in these transactions and there was a significant relationship between these transactions and propping up motivations variables.

Nthoesane (2014) examined various aspects of the economic value added in "research literature". In his view, economic value added is a good tool for measuring the capacity of the management to create value, and it also used to calculate their bonus. However, by reviewing the researches in this field he believes that there is not any relationship between economic value added and Executive compensation, so shareholders do not consider EVA as a proper basis for performance measurement.

Machuga, Pfeiffer, and Verma (2014) in their "economic value added, future accounting earnings and financial analysis in relation to equity return prediction" paper concluded that related party transactions refinement gave extra information to justify future equity variation and also cash flow and income accruals.

Cheong et al. (2014) studied the related parties transactions in listed companies in Hong Kong stock exchange.The results showed that on average, companies which involved in related party transactions earn negative excess return over time periods of up to12 months. This return is significantly low compared with similar transactions fair returns. Excess return has a negative linkage with controlling shareholders ownership percent and Alternative information disclosure policies.

Shariat Panahi and Badavar Nahandi (1384) reviewed the relationship between refined economic value added (REVA) and stock returns. They concluded that refined economic value added (REVA) has a very weak relationship with "variables of the reward to variability" and "ratio of the reward to variability".

Vadiee and Razavirad (2008) in a survey examined the effect of capital on market value added. They concluded that, announcing the news of increasing the capital from cash receivables and share holders' demands affect on the increasing the market value added. To raise equity capital from cash injection and shareholders demand affect on reducing the market value added. Increasing capital from retained earnings has less effect on market value added than shareholders cash injection. In this study, managers are recommended that when the cost of financing through shareholders cash injection is high, they can provide their finance through debt such as bank loans but in situations where the company has profitable investment opportunities, the finance is provided through shareholders cash injection.

Namazi, Heidar Pour, and Mohammadi (1388) in their study investigated the effects of shareholders composition on trading volume and their shares liquidity. In this regard, four hypotheses were supposed in two groups and the relationship between variables were reviewed using correlation method. To investigate the hypothesis, first single-variable correlation coefficient between the predictor variables (individual and institutional shareholders percent) and dependent variables (trading volume and liquidity of shares) were measured. According to the test results, any evidences were not found that share liquidity and trading volume have a linkage with institutional (legal) or non-institutional (natural) shareholders composition.

Khodadadi and Tucker (1390) examined the impact of corporate governance features including the concentration of ownership, institutional investors, government ownership, managerial ownership, duality of the director duties and the percentage of outside directors on the board on the financial performance and firm value. In this context, data from 80 firms listed in Tehran Stock Exchange in the period from 1384 to 1387 were used. The results 
indicated that the concentration of ownership and state ownership have a positive and significant correlation with the performance and the firm value. Major institutional investment had a positive relationship with the firm value but it had a negative relationship with firm performance. The issue of separating the roles of chairman and CEO had a significant and negative correlation with firm value but this correlation was not significant with firm performance. Also the corporate governance structure had a positive and significant relationship with the firm value and performance .

Mehran and Safarzadeh (1390) examined the relationship between corporate governance and earnings quality. In this study, a variety of approaches, including seven methods used to measure earnings quality. The results indicated that corporate governance had a negative and significant linkage with accrual quality standards, earnings persistence, earning smoothing and earning conservatism, and also it had a significant and positive correlation with earnings predictability and asymmetry timeliness of profit. But the findings are not significant for earned value management (EVM). The breakdown of corporate governance index to its components had reduced the explanatory power of the models.

Badavar and colleagues (1390) examined the relationship between corporate governance and accounting conservatism. They found that conservatism had not any significant relationship with institutional ownership, ownership concentration and independence of board members.

Setayesh and ebrahimi (1390) examined the impact of the corporate governance mechanisms on profit information content of listed companies on Tehran's Stock Exchange. In this regard, the effects of ownership concentration variables, managerial ownership, institutional ownership, corporate ownership, board of directors' composition and size on earnings response coefficients were investigated. The results indicated that among research variables only earnings information content had a positive and significant relationship with the ownership concentration and institutional ownership.

Mehrani and colleagues (1390) reviewed the impact of corporate governance mechanisms on earnings management intensity reduction. In this study, logistic regression and Mann-Whitney U test were used. The results showed that the research independent variables cannot limit the aggressive behavior of earnings management. Only if the unmanaged profit was less than last year's reported earnings, non-executive directors reduced such practices to a certain extent.

Talebnia and Shoja (1390) tested the relationship between market value added (MVA) to earning ratio with economic value added (EVA) to earning ratio in listed companies in Tehran Stock Exchange. Their aim was to find an internal performance standard that can be considered as a representative of market value. The findings indicated that there is a positive but weak relationship between market value added to the earnings ratio and economic value added to the accounting earnings ratio. So, from the perspective of the researchers, economic value added to the earning ratio as a measure of internal evaluation model cannot be an efficient standard for market value prediction.

Abbasi and Rastgarnya (1391) examined the impact of ownership structure (concentration and composition) on firm value in Tehran's Stock Exchange. In this respect, 69 firms over1384-1388 have been reviewed. The results showed that major shareholder ownership concentration, major shareholder logarithmic variable, HerfindahlHirschman index, (HHI) had not any significant relationship with corporate value. On the other hand the major shareholder ownership concentration and its logarithmic variable had a meaningful relationship with the firm value.

Moghaddam and Kazemipour (1391) evaluated the "effect of private ownership on the economic value added and return on investment (ROI) in companies listed on Tehran Stock Exchange". Since privatization in recent years has been so highly regarded so it is important to review long-standing and successful privatization programs. This research was conducted over 1383-1386 and its statistical population included all companies listed on Tehran Stock Exchange. The results suggested that the percentage of private sector ownership had a direct and significant relationship with return on assets and economic value added. Also 14 percent economic value-added and $7 \%$ rate of return on assets variations were determinable based on the percentage of private ownership. So there was a significant relationship between the rate of return on assets and the economic value added, but ownership concentration and CEO composition had an insignificant positive relationship with technical performance.

Jalili et al. (1393) assessed "A class of financial metrics that are used to assess a business's ability to generate earnings and financial values to express stock returns of listed companies on Tehran Stock Exchange". The results indicated that among the studied independent variables, economic value added and net income had a significant relationship with equity returns. Other independent variables, as the market value added, cash value added, return on assets and return on equity significantly correlated with stock returns, but this relationship is not as significant as economic value added. 


\section{Research Hypotheses}

By considering the theoretical foundations in this study the reviewed performance criteria included economic value added (EVA), refined economic value added (REVA) and market value added (MVA). The research hypotheses are formulated as follows:

First hypothesis: there is a significant relationship between the economic value added (EVA) and the level of related party transactions.

The second hypothesis: there is a significant relationship between the refined economic value added (REVA) and the level of related party transactions.

The third hypothesis: there is a significant relationship between the market value added (MVA) and the level of related party transactions.

\section{Research Methodology}

\subsection{Statistical Population}

The target population in this study consist all the companies listed on Tehran Stock Exchange. Our purpose to choose the companies listed on the stock exchange is that it is relatively easier to access their financial information. Also, because of regulations and standards of Tehran Stock Exchange, these company's financial reporting information is more homogeneous.

\subsection{Statistical Sample}

In this study, all available data were used to select a sample. First, all companies that could participate in the sample, were selected, then from all existing companies, the companies that do not meet any of the following qualifications removed from this study and finally some of the companies were selected randomly:

* The selected company, should not be financial intermediaries, investment companies, holdings, and banks and leasing companies.

* Their fiscal year ends in 19 of March (29 of Esfand which is last month of Iranian year).

* The firms must be active and their stocks should have been traded in the TSE during the time period of the study (over1386-1392).

* The ratio of related party transactions do not represent more than $1 \%$ of a listed company's assets at the time they are concluded (The fifth paragraph is measured in comparison with the rest of the companies, so The ratio of related party transactions to the assets of all companies is measured, and finally the information is sorted out in Excel software and the companies which their transaction level with their related parties are greater than 1 percent of assets, are included in our study).

Considering above mentioned conditions, 468 firms were selected as our available population sample that if sample size estimation formula is used:

$$
\mathrm{n}=\frac{\mathrm{NZ} \mathrm{Z}_{\alpha / 2}^{2} \mathrm{P}(1-\mathrm{P})}{\varepsilon^{2}(\mathrm{~N}-1)+\mathrm{Z}_{\alpha / 2}^{2} \mathrm{P}(1-\mathrm{P})}
$$

$\mathrm{N}$ : population size;

p: success that is considered $95 \%$;

Z: normal distribution standard variable.

$$
\mathrm{n}=\frac{468 *(1.64)^{2} .95 * .05}{(.05)^{2}(468-1)+1.64 * .95 * .05}=49
$$

$\varepsilon$ : percentage error that is considered 10 percent.

The minimum sample size is 49 , but for a better data analysis the most of those companies that their information were accessible were selected, So the research population included 85 companies (Azar \& Momeni, 1392).

\subsection{The Study Models}

Multiple regression model is used to test the hypothesis:

$$
R P T_{i t}=\beta_{0}+\beta_{1} E V A_{i t}+\beta_{2} R E V A_{i t}+\beta_{3} M V A_{i t}+\beta_{4} \text { Herfindahl }_{i t}+\beta_{5} \text { Bargain }_{\text {it }}+\beta_{6} \text { Size }_{i t}+\beta_{7} \text { Lev }_{i t}+\varepsilon_{i t}
$$

To prevent overlap also independent variables were used separately in the research model, and their impact on 
dependent variable was measured based on control variables.

Multiple regression model is used to test the hypothesis:

Model (1)

$$
R P T_{i t}=\beta_{0}+\beta_{1} E V A_{i t}+\beta_{2} \text { Herfindahl }_{i t}+\beta_{3} \text { Bargain }_{\text {it }}+\beta_{4} \text { Size }_{i t}+\beta_{5} \text { Lev }_{i t}+\varepsilon_{i t}
$$

Model (2)

$$
\text { RPTit }=\beta 0+\beta 1 \text { REVAit }+\beta 2 \text { Herfindahlit }+\beta 3 \text { Bargain }- \text { pit }+\beta 4 \text { Sizeit }+\beta 5 \text { Levit }+ \text { eit }
$$

Model (3)

$$
R P T_{i t}=\beta_{0}+\beta_{1} M V A_{i t}+\beta_{2} \text { Herfindahl }_{i t}+\beta_{3} \text { Bargain }_{i t}+\beta_{4} \text { Size }_{i t}+\beta_{5} \text { Lev }_{i t}+\varepsilon_{i t}
$$

The following variables are used in this model:

1) The dependent variable

The level of related parties transactions (RPT) represents the logarithm of the total amount of related party transactions which were extracted from notes attached to the financial statements (Sheri, 1391).

2) Independent variables

$$
E V A=N O P A T_{t}-\left(W A C C \times C A P I T A L_{t-1}\right)
$$

EVA: economic value added

MVA: market value added which is obtained through determining the difference between market value and book value of shareholders equity.

$\mathrm{MAV}=$ shareholders equity- (stock price) (the number of issued shares)

3) Control variables

Ownership concentration (Herfindahl): Is measured through Square\% stakes held by three biggest shareholders.

Bargaining power (Bargain): Is obtained through dividing the sum of the second and third largest shareholders by the percent shares of the biggest shareholder.

Firm size (Size): Is obtained through the natural logarithm of firm total assets.

Financial leverage (Lev): Is obtained through dividing the firm total debt by its total assets.

\begin{tabular}{|c|c|c|c|c|c|}
\hline Standard deviation & Minimum & maximum & mean & median & Description \\
\hline 1.636117 & 0.000011 & 7.965000 & 4.967019 & 4.701194 & $\begin{array}{l}\text { The level of transactions with related parties (Natural } \\
\text { logarithm of the transaction amount) }\end{array}$ \\
\hline 1.699419 & 7.021427 & 20.90230 & 18.70948 & 18.46118 & $\begin{array}{c}\text { Economic Value Added } \\
\text { (Amount divided by total assets) }\end{array}$ \\
\hline 1.699059 & 6.914955 & 20.79050 & 18.60301 & 18.35397 & $\begin{array}{l}\text { Refined Economic Value Added } \\
\text { (Amount divided by total assets) }\end{array}$ \\
\hline 1.343377 & 5.310380 & 20.70248 & 18.83119 & 18.75919 & $\begin{array}{l}\text { Market value added (MVA) } \\
\text { (Amount divided by total assets) }\end{array}$ \\
\hline 3.242431 & 1.810005 & 72.72727 & 0.507692 & 0.755348 & $\begin{array}{c}\text { Ownership concentration (natural logarithm of Square\% } \\
\text { stakes held by three biggest shareholders) }\end{array}$ \\
\hline 0.253491 & 0.025600 & 1.000000 & 0.547600 & 0.540360 & $\begin{array}{l}\text { balance rights (dividing the sum of the second and third } \\
\text { largest shareholders by the percent shares of the biggest } \\
\text { shareholder by total assets) }\end{array}$ \\
\hline 0.217322 & 0.096415 & 2.729280 & 0.554653 & 0.557564 & Firm size (Natural logarithm of the amount of sale) \\
\hline 0.658222 & 10.29121 & 14.17223 & 11.75326 & 11.81687 & Firm financial leverage \\
\hline
\end{tabular}

\section{Research Hypotheses Testing Results}

\subsection{Descriptive Statistics}

Table 1. Descriptive statistics of the related companies

Table 1 indicates the descriptive statistics including mean, standard deviation, variance, maximum and minimum for all variables in this study. The level of firm related party transactions mean is 4.96 percent. However, the 
standard deviation is 63.1 percent. In the first stage this shows that there is a lot of differences between companies in the level of related party transactions since the companies are different naturally which make them to consider different policies towards the related party transactions.

The correlation coefficient: Table 2 Results of Pearson correlation coefficients for all companies show that the coefficient is recorded on top of each cell and its probability it is inserted below it.

Table 2. Pearson correlation between variables (using all data)

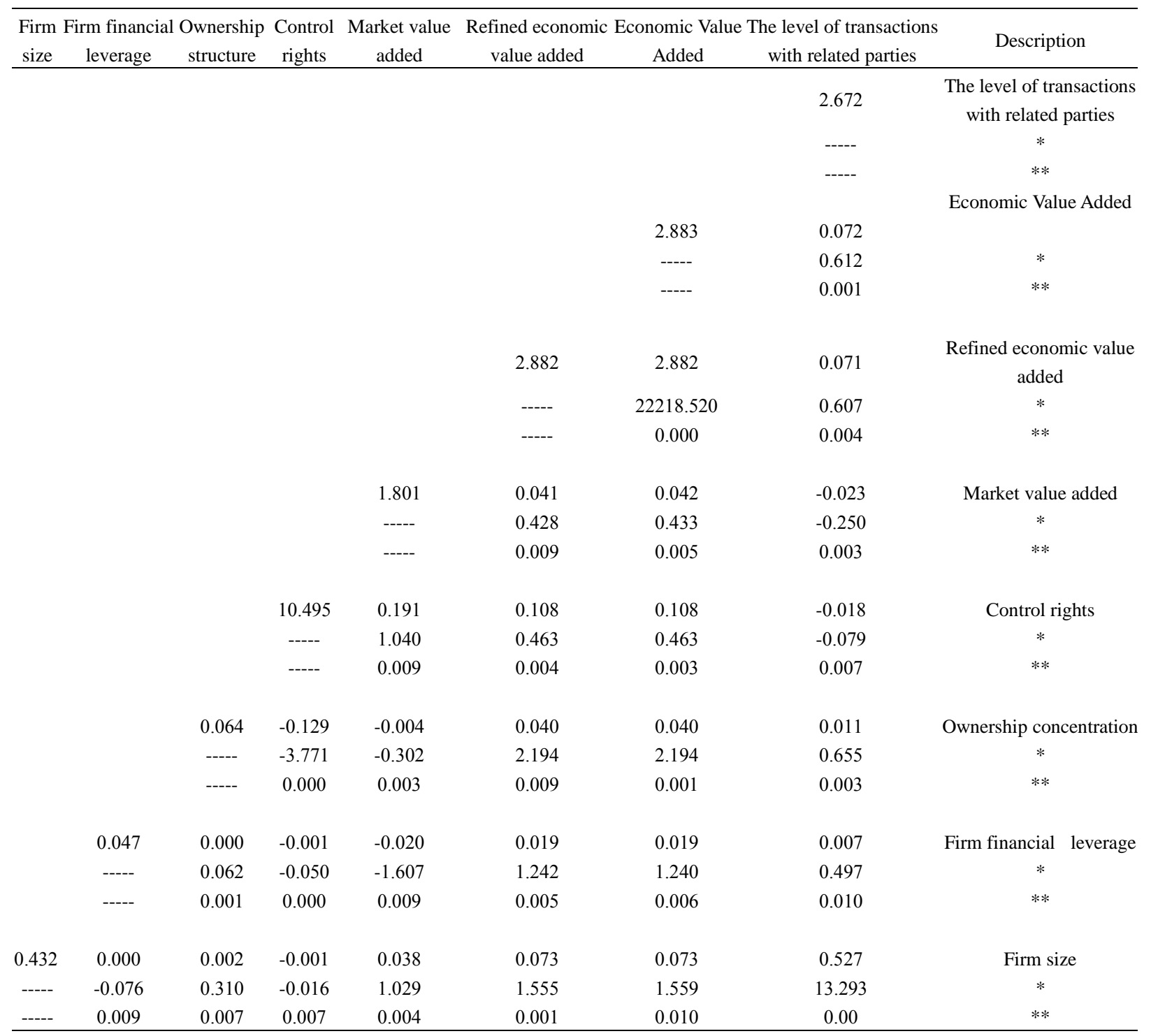

Table 2 shows the results of Pearson correlation analysis of the research variables. As presented in the table, the level of related party transactions has a significant impact on economic value added, refined economic value added and market value added. The positive relationship of firm size suggests that when the firm size is bigger, the possibility of the related party transactions will be increased. Control rights can also increase the effect of related party transactions since when the percent of the second and third biggest shareholders shares is more in relation to the biggest shareholder, the probability of related party transactions is increased. On the other hand the natural logarithm of assets (firm size) has a direct and significant relationship with most financial variables in this research, and its reverse relationship with financial leverage which indicates the nonlinear behavior of these two variables, because, as previously stated in the descriptive statistics, heterogeneous of assets causes their different behaviors.

\subsection{Testing Models and Research Hypotheses}

First hypothesis: there is a significant relationship between the economic value added (EVA) and the level of 
related party transactions.

Table 3. Panel model coefficients with fixed effects between the economic value added (EVA) and the level of related party transactions

\begin{tabular}{llll}
\hline P value & statistical test & coefficients & variables \\
\hline 0.00085 & -1.69485 & -0.06667 & Economic Value Added \\
0.93510 & 0.08143 & 0.00160 & Ownership concentration \\
0.39880 & 0.84455 & 0.21321 & Control rights \\
0.00000 & 11.87595 & 1.17476 & size \\
0.00070 & 0.04928 & 0.01444 & Financial leverage \\
0.00000 & -6.11093 & -8.07268 & Constant coefficient \\
$2 / 47$ & Durbin-Watson statistic & 40 percent & Coefficient of Determination \\
\hline
\end{tabular}

\subsubsection{First Model Testing Results Analysis}

In this hypothesis, the relationship between economic value added (EVA) and the level of related party transactions is discussed. First, the above regression model was fitted to all 596 firms -observations, but after removing extreme values, 562 observations- firms remain for testing the first hypothesis, which results of fittings of this model are as follows: To review the adequacy of the model the testing shows that $\mathrm{F}$ statistical value is equal to 1.508701 which is significantly lower than 0.005 , so the adequacy of the model is confirmed at a confidence level of $95 \%$. As a result, it is accepted that generally this model has the power to determine (a part of the) overall variations of dependent variable based on independent variables.

The coefficient of determination: $\mathrm{R}^{2}$ statistical value shows that the model variables as a whole can explain 40 percent variations in the dependent variable. Also its test statistical value is less than 5 percent and the results of this hypotheses confirm a significant relationship between economic value added and related parties transactions. Also this hypotheses implies that when the level of firm economic profit rises, the managers are more inclined to transact with the related parties. Since based on agency theory, there is a separation of interests between shareholders and managers, the growth of economic value added increases the probability of related party transactions. The results of performance evaluation in this study are also inconsistent with Talebnia and shoja research (1390) on the relationship between the market value added ratio to the accounting earnings and economic value added ratio to accounting earnings, since they find a weak and insignificant relationship between these economic performance variables and accounting earnings.

The second hypothesis: there is a significant relationship between the refined economic value added (REVA) and the level of related party transactions.

Table 4. Panel model coefficients with fixed effects between the refined economic value added (EVA) and the level of related party transactions

\begin{tabular}{cccc}
\hline P value & Statistical test & coefficients & variables \\
\hline 0.00085 & -1.69485 & -0.06667 & refined economic value added \\
0.93510 & 0.08143 & 0.00160 & Ownership Ratio (control rights) \\
0.39880 & 0.84455 & 0.21321 & Control rights \\
0.00000 & 11.87595 & 1.17476 & size \\
0.00070 & 0.04928 & 0.01444 & Financial leverage \\
0.00000 & 4.632315 & 5.025611 & Constant coefficient \\
$2 / 47$ & Durbin-Watson statistic & 40 percent & Coefficient of determination \\
\hline
\end{tabular}

\subsubsection{Second Model Testing Results Analysis}

In this hypothesis, the relationship between refined economic value added (REVA) and the level of related party transactions is discussed. First, the above regression model was fitted to all 596 firms -observations, but after removing extreme values, 562 observations- firms remain for testing the second hypothesis, which results of fittings of this model are as follows: To review the adequacy of the model the testing shows that $\mathrm{F}$ statistical value is equal to 1.508682 which is significantly lower than 0.005 , so the adequacy of the model is confirmed at a confidence level of $95 \%$. As a result, it is accepted that generally this model has the power to determine (a part 
of the) overall variations of dependent variable based on independent variables.

The coefficient of determination: $\mathrm{R}^{2}$ statistical value shows that the model variables as a whole can explain 40 percent variations in the dependent variable. Also its test statistical value is less than 5 percent and the results of this hypotheses confirm a significant relationship between refined economic value added and related party transactions.Also this hypotheses implies that when the level of firm economic profit rises, the managers are more inclined to transact with the related parties. Since based on agency theory, there is not any conflict of interest between shareholders and managers, and increasing refined economic value added also increases the probability of related party transactions. In other words increasing shareholders equity value (market value of shares) attract more investors especially the related parties to invest in these companies. The results of performance evaluation in this study are also inconsistent with Khodadadi and Tucker (1390) research that examines the impact of corporate governance features including ownership concentration, institutional investors, state ownership, managerial ownership, Separate roles for the Chairman and CEO and the percentage of outside directors on the board on firm's financial performance and value . because the results of their research show that by increasing the ratio of ownership (control rights), the level of related party transactions decreases.

The third hypothesis: there is a significant relationship between the market value added (MVA) and the level of related party transactions.

Table 5. Panel model coefficients with fixed effects for market value added (MVA) and the level of related party transactions

\begin{tabular}{cccc}
\hline p-value & Statistical test & coefficients & variables \\
\hline 0.342200 & -0.950756 & -0.046752 & Market value added \\
0.997300 & 0.003331 & 0.000066 & Ownership Ratio (control rights) \\
0.490100 & 0.690657 & 0.174116 & Ownership concentration \\
0.000000 & 11.760440 & 1.162258 & size \\
0.033800 & -0.083151 & -0.24443 & Financial leverage \\
0.000000 & -5.483797 & -8.236527 & Constant coefficient \\
$2 / 48$ & Durbin-Watson statistic & 39 percent & Coefficient of determination \\
\hline
\end{tabular}

\subsubsection{Third Model Testing Results Analysis}

In this hypothesis, the relationship between market value added (MVA) and the level of transactions with related parties is discussed. First, the above regression model was fitted to all 596 firms-observations, but after removing extreme values, 562 observations- firms remain for testing the third hypothesis, which results of fittings of this model are as follows: To review the adequacy of the model, the testing shows that $\mathrm{F}$ statistical value is equal to 1.471331 which is significantly lower than 0.005 , so the adequacy of the model is confirmed at a confidence level of $95 \%$. As a result, it is accepted that generally this model has the ability to determine (a part of the) overall variations of dependent variable based on independent variables.

The modified coefficient of determination: $\mathrm{R}^{2}$ statistical value shows that the model variables as a whole can explain 39 percent variations in the dependent variable. In this test statistical value is more than 5 percent and the results of this hypotheses do not confirm a significant relationship between market value added and related parties transactions. Also this hypotheses implies that since market value added is a result of the difference between book value of equity and shares market value, this difference may be due to the management policies or market conditions that related parties are reluctant to invest or transact in a company due to information asymmetry relative to other investors. So this implies that there is not any significant relationship between market value added (MVA) and the level of transactions with related parties. Also the results of performance evaluation in this study do not necessarily conform with Talebnia and shoja (1390) and Moghaddam and Kazem pour (1391) researches which reviewed financial performance criteria significant relationship with the level of related parties transactions and financial returns.

\section{Recommendations to the Users of the Research Results}

1). Before offering the suggestions, potential users of the research results are recommended to use the results of this study by taking into account the limitations which are mentioned in the previous section.

2). According to the results regarding the impact of economic value added and refined economic value added on the transactions with investors and managers related parties, it is suggested that the investors and the managers 
pay more attention to the above mentioned performance criteria.

3. Since that the economic value added and refined economic value added are considered as influencing measures for the level of related party transactions, it is recommended that Tehran Stock Exchange take actions to provide economic value added and refined economic value added for the companies.

\subsection{Suggestions for Future Research}

1) To review the effect of corporate governance variables including CEO independence, board diversity, the presence of institutional shareholders on the boards and ... on the level of related party transactions.

2) In this research, book value based variables are used to measure the study variables. Therefore, it is suggested that in the future researches market variables also be considered as study variables.

3) To review the effects of the cases as firms life cycle, information asymmetry, liquidity in equities, ... on transaction levels with the related parties.

4) It is possible to conduct a study for periods before and after the implementations of the standards then to review the impact of standards on these ratios in the future.

5) To consider unlisted companies and to conduct similar research about them.

6) To review the relationship between ownership structure (concentration and composition) and the level of related party transactions by exploring shareholders' investment horizons (short-term and long-term).

7) The present research statistical population includes manufacturing companies listed in Tehran Stock Exchange, so the results may not be generalizable to non-listed and non-manufacturing industries. It is suggested that in the future studies their statistical population consist of all manufacturing and non-manufacturing firms, and also in the future studies the relationship between firms economic performance and the level of transactions with related parties in manufacturing and non-manufacturing firms will be determined.

\subsection{Practical Suggestions}

1). Due to the concentrated ownership structure of the business environment in Iran and the fact that firms are more likely to engage in opportunistic behavior in transactions with related parties, it is recommended that national regulatory bodies pay a lot of attention to the subject of related party transactions

2). In this study indirect abuse in related party transactions by observing these transactions linkage with some market variables and firm strategies are studied. So in order to achieve a better results the related party transactions must be considered as an endogenous variable. It is better to assume that shareholders can always decide freely to chooserelated party transaction or not.

\section{Research Limitations}

1). This study like all other descriptive studies have limitations of time and space and its time period covers 7 years from 1386 till 1392 and its sample includes listed companies in Tehran Stock Exchange. Thus caution is needed when generalizing the findings of this study to other times and other statistical populations.

2). Probable impact of differences in accounting methods (such as depreciation calculation method) on the contained items in the financial statements of companies may affect the results of the study and an adjustment has not been made in this regard.

3). Due to the limitations of the statistical population, these limitations should be acknowledged when generalizing the findings of this study to other companies.

4). Accounting researches are often post- event researches so it is not possible to observe the variables directly. Although it should be mentioned that in no research even experimental scientific researches an exact control of the variables is not possible.

5). The political, economical and cultural conditions in Iran and psychological atmosphere prevailing in Tehran Stock Exchange and the awareness level of people participating in the capital market impress supply and demand, the volume of trading and market growth and recession.

\section{References}

Abbasi, I., \& Fatima, R. (1391). The effect of the ownership structure on firms value inTehran Stock Exchange. Journal of Sport Psychology, (5), 33-50.

Alchian, \& Demsetz. (1972). Production, information costs, and economic organization. American Economic Review, 62(December), 777-795. 
Anvari, R., Ali, A., \& Seraji, H. (1383). Investigate stock market value relationship with economic value added (EVA), Earnings Before Interest \& Tax, operating cash flow in listed Tehran Stock Exchange. A Review of Accounting and Auditing, (37).

Bacidore, J. M., John, A. B., Todd, T. M., \& Anjan, V. T. (1997). The Search for the Best Financial Performance Measure. Financial Analysts Journal, May/June, 11-20. http://dx.doi.org/10.2469/faj.v53.n3.2081

Badavr, Y., Brothers, R., \& Mahmoodzadeh, S. (n. d.). A review of the relationship between some corporate governance mechanisms and conservatism in financial reporting. Accounting Research, 9, 130-154.

Baltagi, B. H. (1992). Econometric Analysis of Panel Data (3rd ed.). United Kingdom: Wiley Publishers.

Baltagi, B., Demetriades, P., \& Law, S. H. (2005). Financial Development and Openness: Evidence from panel data. Journal of Development Economic.

Bennedsen, M., \& Wolfenzon, D. (2000). The balance of power in closely held corporations. Journal of Financial Economics, 58, 113-139. http://dx.doi.org/10.1016/S0304-405X(00)00068-4

Bertrand, M., Mehta, P., \& Mullainathan, S. (2002). Ferreting out tunneling: An application to Indianbusiness groups. Quarterly Journal of Economics, 118, 121-148. http://dx.doi.org/10.1162/003355302753399463

Black, E. L. (2005). Life-Cycle Impacts on the Incremental Relevance of Earnings and Cash flow Measures. Journal of Financial Statement Analysis, 40-56.

Chen, F., Hope, O. K., Li, Q., \& Wang, X. (2007). Financial reporting quality and investment efficiency of private firms.

Cheung, Y., Jing, L., Lu, T., Rau, P. R., \& Stouratis, A. (2014). Tunnelling and ProppingUp: An Analysis of Related Party Transactions by Chinese Listed Companies. Social Science Research Network, Working Paper Series. Financial Accounting Standards.

Cheung, Y., Rau, P. R., \& Stouraitis, A. (2005). Tunneling, propping and x ropriation-Evidence from connected party transactions in Hong Kong. Journal of Financial onomics, 82, 343-386. http://dx.doi.org/10.1016/j.jfineco.2004.08.012

De Medeiros, R. O. (2005). Empirical evidence on the relationship between EVA and stock returns in Brazilian firms. http://dx.doi.org/10.2139/ssrn.701421

El Mir, A., \& Souad, S. (2008). Corporate governance and the relationship between EVA and created shareholdervalue. Corporate Governance, 8(1), 46-58. http://dx.doi.org/10.1108/14720700810853392

Fama, E., \& Jensen, M. (1983). Separation of ownership and control. Journal of Law and Economics, 26, 301325. http://dx.doi.org/10.1086/467037

Holmstrom, B., \& Milgrom, P. (1994). The firm as an incentive system. The American Economic Review, 84(4), 972-991.

International Accounting Standards Committee. (1392). Transactions with related parties. Journal of Accounting Standards, 160, 1-33.

Ismail, A. (2006). Is EVA associated with stock return than accounting earnings? The UK evidence. International Journal of Managerial Finance, 2(4), 343-353. http://dx.doi.org/10.1108/17439130610705526

Izadnia, N. (1384). A critical assessment of performance evaluation criteria and the offers of economic value added and free cash flow standards for reporting entity's values (pp. 57-79). Faculty of Economics and Administrative Sciences, University of Isfahan.

Jalili, S. N., Nahre, Ali A., \& Khaleghi, N. (1393). Evaluation of earnings power value (EPV) and profitability indicators in explaining stock returns of companies listed on Tehran Stock Exchange financial knowledge to analyze securities (financial studies) (pp. 77-94).

Jian, M., \& Wong, T. J. (2010). Propping through related party transactions. Review of Accounting Studies, 15, 70-105. http://dx.doi.org/10.1007/s11142-008-9081-4

Johnson, S., La Porta, R., Lopez-de-Silans, F., \& Shleifer, A. (2000). Tunneling. American Economic Review, 90(2), 22-27. http://dx.doi.org/10.1257/aer.90.2.22

Kashani, M., \& Rasaiian, A. (1386). The relationship between value added and performance evaluation indicators in the Tehran Stock Exchange. Accounting Studies, (20), 125-160.

Kerlinger, F. N. (1973). Foundation of behavioral research. New York: Holt Reinhart \& Winston. 
Khodadadi, V., \& Reza, T. (1390). The effect of financial performance and corporate governance structure on listed companies in Tehran Stock Exchange. Journal of Accounting and Auditing Research, (15), 88-109.

La porta, R., Lopez-de-silanes, F., \& Shleifer, A. (1999). Corporate ownership around the world. Journal of Finance, 6(5), 471-518. http://dx.doi.org/10.1111/0022-1082.00115

La Porta, R., Lopez-de-Silanes, F., Shleifer, A., \& Vishny, R. (1999). Legal determinants of external finance. Journal of Finance, 53, 1131-1150.

Liu, D., Lu, L., \& Zhang, H. (2007). Automatic mood detection from acoustic music data. Proceedings of the 4th International Society for Music Information Retrieval Conference (ISMIR 2007).

Machuga, S. M., Pfeiffer, Jr. R. J., \& Verma, K. (2014). Economic value added, future accounting earnings, and financial analysts' earnings per share forecasts. Review of Quantitative Finance and Accounting, 18, 59-73. http://dx.doi.org/10.1023/A:1013814328460

Mashyekhi, S., \& Shahrokhi, S. S. (1383). Factors affecting on capital structure. Accountant, XXI(176).

Mehrani, K., \& Safarzadeh, M. (1390). Determining the relationship between corporate governance and earning quality based on native approach. Journal of Accounting, (7), 69-98.

Mittal, R. K., Sinha, N., \& Singh, A. (2008). An analysis of linkage between economic value added and $\begin{array}{lllll}\text { corporate social } & \text { responsibility. }\end{array}$ http://dx.doi.org/10.1108/00251740810912037

Moghaddam, A., \& Kazem, P. S. (1391). Effect of private ownership on the economic value added (EVA) and Return on Assets (ROA) in the listed companies in Tehran Stock Exchange. Accounting Research, (14).

Moscariello, N. (2013). Related Party Transaction: Opportunistic or Efficient Behavior? Evidence from the Italian Listed Company. Working Paper, Second University of Naples.

Namazi, M., Heidarpour, F., \& Mohammadi, K. (1388). Effect of firms Shareholders composition (natural or legal entities) on their trading volume and share liquidity. Journal of Financial Accounting and Auditing, $1(3), 1-22$.

Noravesh, I., \& Mashyekhi, B. (1383). Incremental information content of economic value added and cash value added in contrast to accounting earnings and cash flow from operations. Financial Research Quarterly, (17), 131-150.

Noravesh, I., \& Salehi, F. (1383). Evaluation of operating cash flows, operating profit and economic value added with wealth created for shareholders. Assessment of Accounting and Auditing, (37).

Panahihan, H. (1382). Application of economic value added (EVA) in financial decision-making. Capital Journal, (3).

Richtard, H. (2000). An Empirical Study of Inflation Distortions to EVA. Journal of Economics and Business, 57(2), 119-137.

Scharfstein, D. S., \& Stein, J. C. (2000). Thedark side of the internal capital markets: Divisional entseekingand inefficient investment. Journal of Finance, 55(6), 2537-2564. http://dx.doi.org/10.1111/0022-1082.00299

Setayesh, M., \& Ibrahimi, F. (1390). A review of the corporate governance mechanisms effect on the earnings information content of listed companies in Tehran Stock Exchange. Journal of Accounting, (8), 31 -48.

Shariatpanahi, S. M., \& Badavrnahandi, Y. (1384). A relatioship between the refined economic value added and refined earning equity based on risk. Accounting Studies Quarterly, (7), 95-77.

Sharma, A., \& Kumar, S. (2010). Economic Value Added (EVA) - Literature Review and Relevant Issues. International Journal of Economics and Finance, 2(2). http://dx.doi.org/10.5539/ijef.v2n2p200

Shery, S., \& Elham, H. (1391). A review of the motivation behind related party transactions. Journal of Empirical Research in Accounting, (6), 49-64.

Shleifer, A., \& Vishny, R. (1997). A survey of corporate governance. Journal of Finance, 52, 737-783. http://dx.doi.org/10.1111/j.1540-6261.1997.tb04820.x

Songhua, H., Yanqin, S., \& Yuehua, X. (2009). Determinants of related-party transactions: Evidence from China's listed companies during 2002-2006. Journal Frontiers of Business Research in China, 3(2), 190206. http://dx.doi.org/10.1007/s11782-009-0010-6

Stewart, G. B. (2000). The Quest for value: A Guide for Senior Managers. 
Talebnia, G., \& Shoja, I. (1390). The relationship between market value added to accounting earnings ratio and economic value added to accounting earnings ratio in listed companies in Tehran Stock Exchange. Journal of Accounting Management, (8).

Thoesane, B. D., \& Brusco, S. (2014). The Economic Value Added (EVA): An Analysis ofMarket Reaction. Advances in Accounting, 20, 265-290 .

Vadii, R. R. (1387). A review of the effect of capital on market value added in listed companies in Tehran Stock Exchange. Journal of Knowledge \& Development, (23).

Weaver, S. C. (2001). Measuring Economic Value Added: A Survey of the Practices of EVA Proponents. Journal of Applied Finance, 11, 50-61.

Xiangjian, Z., Dongjing, W., \& Jin, X. (2007). Related party transactions and tunneling activities of controlling shareholders (pp. 53-64).

Yeh, Y. H., Shu, P. G., \& Su, Y. H. (2012). Related-party transactions and corporate governance: The evidence from the taiwan stock market. Pacific-Basin Finance Journal, 20, 755-776. http://dx.doi.org/10.1016/j.pacfin.2012.02.003

\section{Copyrights}

Copyright for this article is retained by the author(s), with first publication rights granted to the journal.

This is an open-access article distributed under the terms and conditions of the Creative Commons Attribution license (http://creativecommons.org/licenses/by/3.0/). 